\title{
Ervaringen met het baten-lastenstelsel bij de rijksoverheid
}

\author{
Drs. R.P. van Oosteroom RA RC en mw. drs. M.A. Soons RC
}

\section{Inleiding}

De rijksoverheid in Nederland voert momenteel twee administratieve stelsels naast elkaar: het geïntegreerde verplichtingen-kasstelsel en het baten-lastenstelsel. Het geïntegreerde verplichtingen-kasstelsel is met de Operatie Comptabel Bestel geïntroduceerd omdat het overheidstekort tekenen van onbeheersbaarheid begon te vertonen (Ministerie van Financiën, 1983). Door naast de uitgaven en ontvangsten ook de verplichtingen systematisch te administreren wordt de beheersbaarheid van (toekomstige) uitgaven vergroot.

In het geïntegreerde verplichtingen-kasstelsel vormt de kas de centrale aansturingsgrootheid. Het stelsel wordt gekenmerkt door het hanteren van een jaargrens voor de besteding van middelen. In het rapport 'Verder bouwen aan beheer' is aangegeven dat voor bepaalde diensten een optimale bedrijfsvoering slechts te bereiken is door verdergaande speciale beheersregels te creëren (Ministerie van Financiën, 1991). In datzelfde rapport is de comptabele figuur van het agentschap

Drs. R.P. (Ronald) van Oosteroom RA RC studeerde bedrijfseconomie en accountancy aan de Rijksuniversiteit Groningen en volgde de controllersopleiding aan de Erasmus Universiteit Rotterdam. Hij werkt sinds 1993 bij het Ministerie van Financiën. Momenteel is hij bij de Directie Begrotingszaken hoofd van de afdeling bedrijfsvoering en verzelfstandigingen.

Mw. drs. M.A. (Angélique) Soons RC studeerde bedrijfseconomie aan de Katholieke Universiteit Brabant en volgde de controllersopleiding aan de Erasmus Universiteit Rotterdam. Zij werkte van 1992 tot en met 1998 bij het Ministerie van Onderwijs, Cultuur en Wetenschappen. Sinds 1999 is zij werkzaam bij de Directie Begrotingszaken van het Ministerie van Financiën, momenteel als plaatsvervangend hoofd van de afdeling bedrijfsvoering en verzelfstandigingen. geïntroduceerd (inmiddels vervangen door de term baten-lastendienst) $)^{2}$. Aan onderdelen van ministeries is het onder voorwaarden toegestaan in combinatie met een resultaatgericht besturingsmodel het in het bedrijfsleven gangbare batenlastenstelsel te voeren. Kenmerkend voor dit stelsel is dat uitgaven aan perioden en producten worden toegerekend. De kas vormt niet langer de centrale aansturingsgrootheid.

Het kabinetsbeleid is er lange tijd op gericht geweest om daar waar de baten van invoering van het baten-lastenstelsel opwegen tegen de kosten ervan, over te stappen op het nieuwe stelsel (Tweede Kamer, 1996). Per 1 januari 2001 hebben 23 diensten deze overstap gemaakt en heeft dit stelsel dus ook binnen de rijksoverheid vaste voet aan de grond gekregen ${ }^{3}$. Met dit artikel wordt beoogd om lessen te trekken uit de ervaringen van baten-lastendiensten voor de integrale invoering van het baten-lastenstelsel.

\section{Geen zuivere stelsels}

Uit de inleiding blijkt al dat het afgelopen decennium het geïntegreerde verplichtingen-kasstelsel en het baten-lastenstelsel naast elkaar gebruikt worden binnen de rijksoverheid. Van beide stelsels zijn in de praktijk de scherpe kantjes afgehaald. In de geïntegreerde verplichtingen-kasadministratie zijn elementen van het baten-lastenstelsel opgenomen, net zo zeer als in de baten-lastenadministratie kassturingselementen zijn behouden dan wel heringevoerd.

Het geïntegreerde verplichtingen-kasstelsel werkt genuanceerder dan een zuiver kasstelsel. Het eerder genoemde rapport 'Verder bouwen aan beheer' heeft daarvoor in belangrijke mate de basis gelegd. Waar in een zuiver kasstelsel de jaargrenzen hard zijn in de zin dat uitgaven en ontvangsten niet vrijelijk van het ene op het andere begrotingsjaar meegenomen kunnen worden, is dit doorbroken in het geïntegreerde verplichtingen- 
kasstelsel. Onderkend werd dat strikte toepassing van het kasstelsel tot een ondoelmatige aanwending van overheidsgelden kan leiden. Om dit tegen te gaan is de eindejaarsmarge geïntroduceerd: een vast percentage van het uitgaventotaal van de ontwerpbegroting kan over de jaargrens heen worden geschoven. Ook zijn er mogelijkheden voor intertemporele compensatie waarbij onder bepaalde voorwaarden budgetten tussen opeenvolgende begrotingsjaren kunnen worden verschoven. Daarnaast bestaat de mogelijkheid om een begrotingsfonds te vormen. Dit betreft een constructie waarin een afzonderlijke begroting voor verplichtingen, uitgaven en ontvangsten voor een specifiek doel wordt opgesteld en waarbij niet aangewende ontvangsten beschikbaar blijven voor een volgend begrotingsjaar. Een belangrijk voorbeeld hiervan is het Infrastructuurfonds. Ook binnen de bestaande begrotingen is recentelijk de mogelijkheid geopend om één of meerdere interne begrotingsreserves aan te houden. Hiermee wordt voorkomen dat ministeries begrotingsgelden, die over de jaargrenzen heen benodigd zijn, buiten de rijksbegroting aanhouden in bijvoorbeeld stichtingen (Bestebreur e.a., 2000).

Bovengenoemde aanpassingen op het zuivere kasstelsel introduceren een tijdsdimensie, kenmerkend voor het baten-lastenstelsel, in het geïntegreerde verplichtingen-kasstelsel.

Het binnen de rijksoverheid toegepaste batenlastenstelsel heeft eveneens een ontwikkeling ondergaan. Bij de introductie van de comptabele figuur is er bewust voor gekozen om baten-lastendiensten geen mogelijkheid te geven om een zelfstandig beroep te doen op de kapitaalmarkt. Dit had tot gevolg dat baten-lastendiensten eerst moesten reserveren en/of afhankelijk waren van een investeringsbijdrage van het moederministerie voor het doen van investeringen. Bij een aantal baten-lastendiensten heeft dit tot knelpunten in de bedrijfsvoering geleid. Met de introductie van de interne leen- en depositofaciliteit is het binnen de rijksoverheid toegepaste baten-lastenstelsel meer marktconform geworden. Toch blijven er verschillen. Baten-lastendiensten zijn integraal onderdeel van het Rijk als geheel. Het is niet doelmatig om op decentraal niveau grote reserves aan te houden, zelfs als deze vanuit bedrijfseconomisch perspectief verantwoord zijn. Hierbij wordt gerefereerd aan reserves die aangehouden worden om (toekomstige) activa te financieren. Binnen de rijksoverheid heeft het eigen vermogen derhalve in principe geen financieringsfunctie meer. De vaste activa worden gefinancierd met vreemd vermogen. Vanuit deze optiek is er eveneens voor gekozen om het resterende eigen vermogen te maxime- ren op een vast percentage van de omzet (Van Oosteroom e.a., 2000).

Kenmerkend voor het baten-lastenstelsel is dat gestuurd wordt op het verloop van de kosten en opbrengsten. Dit wil niet zeggen dat de kas niet meer belangrijk is. Integendeel, 'geld kost immers geld'. Echter, doordat binnen de rijksoverheid nog steeds het geïntegreerde verplichtingen-kasstelsel domineert, is de nadruk blijven liggen op de kassturing. Dit komt tot uitdrukking in de wijze waarop de Staten-Generaal de begroting van de baten-lastendiensten autoriseert. Naast kosten en opbrengsten gaat het eveneens om kapitaaluitgaven en kapitaalontvangsten. Op deze wijze is in het baten-lastenstelsel tot op heden de autorisatie van de kas behouden.

Uit het voorgaande blijkt dat van het binnen de rijksoverheid toegepaste geïntegreerde verplichtingen-kasstelsel en het baten-lastenstelsel de scherpe kantjes zijn afgehaald en deze twee stelsels steeds dichter bij elkaar zijn komen te liggen. Dit in combinatie met het feit dat een steeds groter deel van de rijksoverheid op het baten-lastenstelsel is overgestapt dan wel deze overstap gaat maken, roept de vraag op in hoeverre het zinvol en wenselijk is om twee stelsels naast elkaar te laten bestaan. In haar advies op de zevende wijziging van de Comptabiliteitswet merkt de Raad van State op: 'De mogelijkheid tot invoering van het baten-lastenstelsel voor de gehele rijksoverheid betekent dat twee systemen naast elkaar gaan bestaan: het baten-lastenstelsel en het verplichtingen-kasstelsel. Dit komt de vergelijkbaarheid van de verschillende onderdelen van de Rijksbegroting niet ten goede, hetgeen ook gevolgen heeft voor de uitoefening van de controlerende taak door de Staten-Generaal.....Daarbij mist de Raad voorts .... een beargumenteerde visie op het uiteindelijk gewenste begrotingsstelsel'(Tweede Kamer, 1999d).

\section{Naar een integraal baten-lastenstelsel}

Het dichter bij elkaar komen te liggen van het verplichtingen-kasstelsel en het baten-lastenstelsel en de roep om eenduidigheid in het te hanteren stelsel, maakten het onvermijdelijk dat de keuze uiteindelijk op het baten-lastenstelsel zou vallen. In de Miljoenennota 2001 (Tweede Kamer, 2000a) staat het principebesluit tot integrale invoering van het baten-lastenstelsel als volgt verwoord: 'Met de introductie van de beleidsbegroting op Prinsjesdag 2001 zal een belangrijke stap gezet worden op de weg naar een overheid die - meer dan tot nu toe het geval is - resultaatgeoriënteerd is. In de beleidsbegroting zal ... immers sprake 
zijn van een koppeling tussen beleidsprestaties, beleidsinstrumenten en middelen.... Het huidige begrotingsstelsel - het zogenaamde verplichtingen-kasstelsel - is niet het geëigende stelsel voor een dergelijke resultaatgeoriënteerde begroting. Een baten-lastenstelsel - zoals het bedrijfsleven, decentrale overheden en inmiddels ook een groot aantal onderdelen van de rijksdienst dat ook hanteren - is daarvoor geschikter. Daarom is het kabinet voornemens om over enkele jaren de gehele rijksbegroting te baseren op het batenlastenstelsel.'

$\mathrm{Nu}$ het principebesluit eenmaal genomen is, staat een grootschalig implementatietraject voor de deur. Om deze implementatie zo soepel mogelijk te laten verlopen, is het van belang te leren van de ervaringen die al met het baten-lastenstelsel bij de baten-lastendiensten zijn opgedaan.

Achtereenvolgens komen aan de orde: resultaatgericht besturingsmodel (paragraaf 4), transparantie van de overheidsprestaties (paragraaf 5), kwaliteit van de bedrijfsvoering (paragraaf 6), begrotingsnormering (paragraaf 7), democratische controle (paragraaf 8), vermogensvorming (paragraaf 9), financiële implicaties van invoering (paragraaf 10) en veranderingsmanagement (paragraaf 11). Tot slot worden enkele rijksbrede lessen uit de ervaringen met de baten-lastendiensten samengevat (paragraaf 12).

\section{Resultaatgericht besturingsmodel}

Een belangrijk beginsel van het baten-lastenstelsel is het matchingbeginsel: het toerekenen van uitgaven aan de periode waarin de opbrengsten van de producten waarvoor de kosten zijn gemaakt als baten worden verantwoord. Zonder op de producten en diensten te sturen, is de toepassing van dit beginsel (en daarmee van het baten-lastenstelsel) een louter boekhoudkundige exercitie. De kracht van het baten-lastenstelsel wordt dan onvoldoende benut. De meerwaarde van het baten-lastenstelsel is dan ook het grootst als het stelsel wordt toegepast in combinatie met een resultaatgericht besturingsmodel. Een dergelijk besturingsmodel stelt sturing op hoofdlijnen, bekostiging op basis van de geleverde prestaties en afrekening op resultaten centraal.

De invoering van een resultaatgericht besturingsmodel is echter nog niet zo eenvoudig. De ervaringen met de baten-lastendiensten hebben dat aangetoond. Hierbij is een aantal kritische succesfactoren naar voren gekomen dat geleid heeft tot de nadere operationalisering van de instellingsvoorwaarden van baten-lastendiensten (Tweede Kamer, 1999a). In de eerste plaats betreft dit het nadrukkelijk onderscheiden van de verschillende rollen die vervuld worden: eigenaar, opdrachtgever en opdrachtnemer. ${ }^{4}$. Een en ander moet leiden tot een duidelijke toedeling van verantwoordelijkheden en bevoegdheden die gepaard gaat met het zoveel mogelijk in één hand brengen van het bepalen, betalen en genieten. Een tweede kritische succesfactor betreft de identificatie van de producten en diensten, die het aangrijpingspunt voor de sturing zijn. De derde kritische succesfactor betreft het vormgeven en op elkaar aansluiten van de interne en externe planning- en controlcyclus.

De huidige baten-lastendiensten zijn veelal uitvoeringsorganisaties. Voor die organisaties zou het relatief eenvoudig moeten zijn om te voldoen aan de genoemde kritische succesfactoren. Uit de evaluaties van diverse baten-lastendiensten blijkt dat dit niet altijd over de gehele linie opgaat. Met name voor activiteiten die een meer beleidsmatig karakter hebben, zoals beleidsadvisering en toetsen van wet- en regelgeving, is een resultaatgerichte besturing minder eenvoudig te realiseren. Dergelijke activiteiten zijn veelal moeilijker te vertalen in stuurbare en meetbare producten en diensten.

Het grootste deel van de rijksoverheid dat de overstap nog moet maken naar het baten-lastenstelsel, houdt zich niet bezig met de uitvoering maar met de vorming van beleid. Gelet op de ervaringen bij baten-lastendiensten mag gesteld worden dat sturen op resultaat complexer zal zijn. Om te kunnen sturen op producten en diensten moet ervoor gezorgd worden dat deze voldoende homogeen, meetbaar, representatief en reproduceerbaar zijn. Naar verwachting zal het aantal verschillende producten en diensten zo groot zijn dat de transparantie en daarmee de stuurbaarheid in het geding komen. Vandaar dat een zekere mate van clustering zal moeten plaatsvinden. De ervaringen bij de baten-lastendiensten leren dat het van belang is dat de producten en diensten zowel het aangrijpingpunt voor de interne als externe sturing vormen. Verder leren de baten-lastendiensten dat de hiervoor benodigde tijd niet onderschat moet worden.

\section{Transparantie van de overheidsprestaties}

Prestatiegegevens gaan een steeds belangrijkere rol spelen bij het geven van inzicht in het presteren van overheidsdiensten. Waar tot voor kort de nadruk lag op volume- en prijsgegevens is nu met 'Van beleidsbegroting tot beleidsverantwoording' (VBTB) een ontwikkeling gaande om meer inzicht te geven in de doelmatigheid en doeltreffendheid (Tweede Kamer, 1998a). 
Bij baten-lastendiensten is het transparant maken van prestaties van begin af aan een belangrijk thema. Het gaat immers om het maken van duidelijke afspraken over de productie, over de daarvoor beschikbare middelen alsmede over positieve en negatieve sancties die verbonden zijn aan het al dan niet behalen van de prestaties. Een en ander vanuit de gedachte dat dit een positief effect kan hebben op de doelmatigheid van de organisatie. Daarbij spelen prestatiegegevens een belangrijke rol: 'Via dergelijke indicatoren kan vooraf een aanduiding worden gegeven van hoe men zo effectief en doelmatig mogelijk met de beschikbare middelen wil omgaan. En achteraf vormen de indicatoren een maatstaf om het gevoerde beheer te toetsen.' (Ministerie van Financiën, 1991)

De rijksbrede evaluatie van het agentschapmodel heeft laten zien dat aan het begrip doelmatigheid in de praktijk een financiële betekenis is gegeven (Ministerie van Financiën, 1998). Nagenoeg alle baten-lastendiensten volgden de ontwikkeling van de kosten in de tijd. Dit leidt tot transparantie van de bedrijfsprocessen en vergroot de mogelijkheden voor resultaatgerichte sturing. Dit is overigens inherent aan het feit dat deze diensten een batenlastenstelsel voeren. Het volgen van de kosten hoeft niet meer extracomptabel te geschieden. Het vergelijken van de kosten in de tijd zegt evenwel niets over doelmatigheid. Een wijziging in de hoogte van de kostprijzen krijgt pas een betekenis wanneer dit in relatie wordt gezien met de kwaliteit van de desbetreffende producten en diensten. Het kunnen aantonen van doelmatigheid werd verder gecompliceerd doordat bij de meeste batenlastendiensten de set van indicatoren in de eerste jaren nog sterk in beweging was. De prestatieindicatoren moesten noodgedwongen snel aangepast worden, waardoor een vergelijking in de tijd van de doelmatigheid minder goed of niet mogelijk was. De ervaring bij de baten-lastendiensten is, dat om iets te kunnen zeggen over doelmatigheid, het belangrijk is om over een samenhangende set van prestatie-indicatoren te beschikken die voldoende stabiel in de tijd is.

\section{Kwaliteit van de bedrijfsvoering}

In de vorige paragrafen is geconcludeerd dat de meerwaarde van de integrale invoering van het baten-lastenstelsel het grootst is als dit gecombineerd wordt met resultaatgerichte sturing, waarbij prestatiegegevens (waaronder de kostprijzen) een belangrijke rol spelen.

Uit de rijksbrede evaluatie van de baten-lastendiensten is naar voren gekomen dat voor de identi- ficatie van producten en diensten alsmede voor de bepaling van de bijbehorende kostprijzen, een beschrijving van de bedrijfsprocessen noodzakelijk is. De praktijk leert dat het inzichtelijk maken van de bedrijfsprocessen potentiële kwaliteitsverbeteringen zichtbaar maakt (Ministerie van Financiën, 1998). Hieruit valt af te leiden dat een resultaatgerichte sturing in combinatie met het voeren van een baten-lastenadministratie een impuls voor de kwaliteit van de bedrijfsvoering kan opleveren.

Tegelijkertijd leert de ervaring met de batenlastendiensten dat het financieel beheer tijdens het implementatietraject in de verdrukking kan komen. 'Het feit dat meer dan de helft van het aantal agentschappen (ernstige) tekortkomingen in het financieel beheer kent, sommige al voor de instelling, geeft de Rekenkamer de indruk dat te snel tot agentschapsvorming wordt overgegaan' (Algemene Rekenkamer, 2000). De aanpassingen in het financieel beheer, nodig door de overgang van het verplichtingen-kasstelsel naar het batenlastenstelsel, hebben over het algemeen geen hoge prioriteit in het veranderingstraject gekregen. Daarmee ontbreekt een belangrijke voorwaarde om de doelstelling van het agentschapmodel te kunnen bereiken. Immers, om de doelmatigheid te vergroten, is een gezonde bedrijfsvoering, waaronder financieel beheer, essentieel. Inmiddels wordt in de instellingsprocedure voor batenlastendiensten expliciet aandacht besteed aan de kwaliteit van het financieel beheer en de benodigde aanpassingen. Een zorgvuldige voorbereiding van de invoering en enige ruimte ervoor is onontbeerlijk.

\section{Begrotingsnormering}

Een ongestoorde bedrijfsvoering is gebaat met het kunnen doen van investeringen op het voor de organisatie meest geschikte moment. Wanneer de rentabiliteit van een investering positief wordt beoordeeld, zou daadwerkelijk geïnvesteerd moeten worden. In de praktijk is gebleken dat batenlastendiensten niet altijd over voldoende eigen middelen beschikken voor het doen van investeringen. Inpassen in de begroting van het moederministerie bleek niet altijd mogelijk, met als gevolg uitstel van investeringen. De facto werden investeringsuitgaven vanwege de kaseffecten gediscrimineerd ten opzichte van consumptieve uitgaven. In het huidige model baten-lastendienst is het effect hiervan geneutraliseerd door de introductie van de leenfaciliteit (Ministerie van Financiën, 1999b). Timing van investeringen is daardoor beter mogelijk. 
Bij de vormgeving van een rijksbreed baten-lastenstelsel is een meer evenwichtige benadering van investerings- en consumptieve uitgaven een belangrijk aandachtspunt. Gedacht wordt aan het vaststellen van kostenkaders in plaats van uitgavenkaders (Tweede Kamer, 1996). Echter, sinds de toetreding van Nederland tot de Europese Monetaire Unie (EMU) vormt het EMU-saldo een belangrijke begrotingsnorm. Deze luidt in kastermen (op transactiebasis) en niet in kostentermen. In enig jaar kunnen de uitgaven groter zijn dan de kosten. Het effect hiervan was, zij het in het klein, al te zien bij baten-lastendiensten. De regelgeving rond baten-lastendiensten is dusdanig vormgegeven dat in het uiterste geval het EMU-saldo leidend is: als het EMU-saldo in de gevarenzone zou komen, heeft de minister van Financiën de mogelijkheid om het beroep op de leenfaciliteit te reguleren.

Ook bij de integrale invoering van het batenlastenstelsel zal inzichtelijk gemaakt moeten worden hoe kas en kosten zich tot elkaar verhouden.

\section{Democratische controle}

De Tweede Kamer heeft de zorg geuit dat de kwaliteit van de democratische controle door het batenlastenstelsel zal inboeten: men vreest een beperking van de autorisatiemogelijkheden (Tweede Kamer, 1998b).

De invoering van baten-lastendiensten heeft de dialoog tussen de Staten-Generaal en de voor baten-lastendiensten verantwoordelijke vakminister beïnvloed. Baten-lastendiensten worden intensiever dan reguliere onderdelen van ministeries door de Staten-Generaal gevolgd (Tweede Kamer, 1999d). Materieel is de autorisatiefunctie van de Staten-Generaal wat betreft baten-lastendiensten niet gewijzigd: het autorisatierecht ten aanzien van de uitgaven en ontvangsten is 'ingewisseld' voor het autorisatierecht van baten en lasten aangevuld met kapitaalontvangsten en kapitaaluitgaven. Zoals in paragraaf $2 \mathrm{al}$ is aangegeven is dit dubbele aangrijpingspunt voor autorisatie met name geïntroduceerd omdat het merendeel van de rijksoverheid werkt met het geïntegreerde verplichtingen-kasstelsel.

De overstap naar een integraal baten-lastenstelsel maakt dat een bezinning op de wijze van parlementaire controle in de rede ligt. Een en ander in relatie tot de wijze waarop het thema 'begrotingsnormering' wordt uitgewerkt.

De zorg ten aanzien van de kwaliteit van de democratische controle richt zich ook op een ander aspect. Daarbij wordt met name gedoeld op de beïnvloedbaarheid van de hoogte van de jaar- lijkse kosten en opbrengsten. Inherent aan het baten-lastenstelsel zijn de verschillende keuzemogelijkheden ten aanzien van bijvoorbeeld de waarderingsgrondslagen, afschrijvingstermijnen en voorzieningen (Tweede Kamer, 2000c). De hierbij behorende gedragseffecten zijn nog onbekend. Om een begroting in termen van baten en lasten te kunnen begrijpen en beoordelen, is transparantie ten aanzien van de gemaakte keuzes essentieel.

De ervaringen met de verslaggevingsvoorschriften voor baten-lastendiensten leren dat het niet mogelijk en wenselijk zal zijn om de (arbitraire) keuzemogelijkheden geheel uit het stelsel te halen. Enige flexibiliteit is noodzakelijk om recht te doen aan de eigenheid van de primaire processen en de daaruit voortvloeiende bedrijfsrisico's van de verschillende baten-lastendiensten. Dit ligt in lijn met de wijze waarop de verslaggevingsvoorschriften in de private sector zijn vormgegeven. Wel is een tendens richting een nadere uniformering zichtbaar. Om tegemoet te komen aan de zorg ten aanzien van de kwaliteit van de parlementaire controle zal de nog op te stellen wet- en regelgeving voor de rijksoverheid in eerste instantie vrij stringente voorschriften bevatten. Naarmate meer ervaring is opgedaan zal bezien worden in hoeverre het mogelijk en wenselijk is om meer vrijheidsgraden toe te staan.

\section{Vermogensvorming}

Kenmerkend voor het baten-lastenstelsel is de toerekening van uitgaven en ontvangsten aan perioden: het werken met baten en lasten. In de staat van baten en lasten wordt zichtbaar gemaakt in hoeverre de jaarlijkse exploitatie kostendekkend is. Het resultaat wordt weerspiegeld in de mutatie van het eigen vermogen. Een positief resultaat leidt daarbij tot een toename van het eigen vermogen.

Het Rijk heeft in tegenstelling tot de private sector geen winstoogmerk. Wel wordt gestreefd naar doelmatigheid en doeltreffendheid. Reserves, veelal geheel of gedeeltelijk in liquide middelen aangehouden, beletten de Staten-Generaal deze middelen voor andere politieke doelstellingen aan te wenden. Gelet op het voorgaande is het dus zaak om het eigen vermogen zoveel mogelijk te beperken. Een en ander met inachtneming van de twee functies die het eigen vermogen kan hebben: een financieringsfunctie en een bufferfunctie.

Zoals al eerder in dit artikel is aangegeven, is er ten aanzien van baten-lastendiensten voor gekozen om het eigen vermogen uitsluitend te gebruiken als buffer om tegenvallers in de exploitatie te 
kunnen opvangen. De omvang van deze buffer is bovendien gemaximeerd (Tweede Kamer, 1999b) . Voor de financiering van investeringen is een interne leenfaciliteit bij het Ministerie van Financiën beschikbaar gesteld.

Ook bij de integrale invoering van het baten-lastenstelsel zal het vraagstuk van vermogensvorming van betekenis zijn. In de discussie is een aantal aspecten van belang. In de eerste plaats moet onnodige reservevorming, met het oog op een evenwichtige allocatie van middelen, voorkomen worden. Daarbij zal een balans gezocht moeten worden met een tweede aspect: prikkels voor een doelmatige bedrijfsvoering. Een en ander met behoud van transparantie.

\section{Financiële implicaties voor invoering}

Aan de overgang van een geïntegreerde verplichtingen-kasadministratie naar een baten-lastenadministratie zijn kosten verbonden. De kosten zijn divers van aard en hangen veelal samen met aan te brengen organisatorische en administratieve veranderingen. De baten-lastendiensten die de overstap al gemaakt hebben, geven in het algemeen aan dat de kosten vooral betrekking hebben op de aanschaf van softwarepakketten die een baten-lastenadministratie mogelijk maken, opleidingskosten van personeel alsmede de inhuur van tijdelijk personeel om het veranderingstraject vorm te geven. Vooralsnog zijn - helaas - geen specifieke gegevens beschikbaar over de omvang van de hiermee gemoeide bedragen. Landen als Australië en Nieuw-Zeeland, die de overstap naar het batenlastenstelsel al gemaakt hebben, kunnen evenmin duidelijkheid geven over de implementatiekosten (Tweede Kamer, 2000b).

Juist omdat de baten van een integrale overstap moeilijk te kwantificeren zijn, is het van belang om al in de beginfase een indicatie te hebben van de financiële implicaties van de invoering en deze middelen ook beschikbaar te hebben. Het gedurende het veranderingstraject moeten vergaren van de benodigde middelen zet een te grote druk op de voortgang en op het draagvlak van de integrale invoering van het baten-lastenstelsel. De ervaringen bij baten-lastendiensten kunnen behulpzaam zijn bij het geven van een dergelijke indicatie. Tevens kunnen zij inzicht geven in de aard van de te verrichten inspanningen. Aangezien zij een dergelijk proces al doorlopen hebben, kunnen zij bijvoorbeeld handreikingen geven voor het functioneel ontwerp van een administratief systeem, dan wel opleidingseisen voor het personeel.

\section{Verandermanagement}

Het integraal invoeren van het baten-lastenstelsel vormt een ingrijpend veranderingsproces. Te denken valt aan het leren denken in termen van kosten, hetgeen nog niet zo eenvoudig is. Verder ook het begrijpen van informatie uit een baten-lastenadministratie zoals een balans, een staat van baten en lasten en een kasstroomoverzicht en het sturen op deze informatie. Het veranderingsproces is wat betreft omvang vergelijkbaar met de Operatie Comptabel Bestel, die midden jaren tachtig is aangevangen. Het gedeeltelijk samenvallen met de implementatie van VBTB, vraagt om het goed managen van dit veranderingsproces.

De baten-lastendiensten hebben dit veranderingsproces reeds doorgemaakt. Deze diensten hebben over het algemeen te maken gehad met een korte invoeringsperiode en daardoor het invoeringsproces intensief beleefd. De ervaringen van deze diensten zijn dat commitment bij de leiding en draagvlak bij de medewerkers cruciaal zijn. Er moet voldoende tijd voor de invoering beschikbaar zijn. Het proefdraaien met een batenlastenadministratie kan belangrijke leermomenten opleveren en kan eveneens bijdragen aan het draagvlak. Hetzelfde geldt voor het proefdraaien met het erbij behorende sturingsmodel. Herkenbare (kleine) stapjes zijn in dat kader eveneens te noemen (Ter Bogt e.a., 2000; Ministerie van Financiën, 1998). De les die uit de implementatie van VBTB te trekken is, betreft het belang van helder communiceren over de andere manier van begroten en verantwoorden.

\section{Rijksbrede lessen}

De selectieve invoering van het baten-lastenstelsel bij enkele uitvoerende onderdelen van ministeries heeft de gelegenheid geboden om in de praktijk ervaringen op te doen. Deze ervaringen komen goed van pas nu in de Miljoennenota 2001 het principebesluit tot integrale invoering van het baten-lastenstelsel is opgenomen. Ter afsluiting van dit artikel worden de belangrijkste lessen samengevat:

1. De meerwaarde van het baten-lastenstelsel is het grootst als het stelsel wordt toegepast in combinatie met een resultaatgericht besturingsmodel.

2. Om iets te kunnen zeggen over doelmatigheid, moet over een samenhangende set van prestatie-indicatoren worden beschikt die voldoende stabiel in de tijd is.

3. Een zorgvuldige voorbereiding van de implementatie en enige ruimte om aanpassingen aan 
te brengen in de bedrijfsvoering (waaronder financieel beheer) is noodzakelijk.

4. Om investerings- en consumptieve uitgaven gelijkwaardig te behandelen, is sturing op kosten noodzakelijk. Het is met het oog op het EMU-saldo belangrijk om daarbij inzicht te hebben in de omvang en de waarschijnlijkheid van het risico dat het uitgavenniveau (substantieel) afwijkt van de kostenkaders.

5. Het is niet mogelijk en niet wenselijk om de (arbitraire) keuzemogelijkheden geheel uit het baten-lastenstelsel te halen, hoewel uit hoofde van het zekerstellen van de parlementaire controle wel de neiging tot zo uniform mogelijke voorschriften zal bestaan.

6. Er moet een balans gevonden worden tussen onnodige reservevorming (met het oog op een evenwichtige allocatie van middelen) en prikkels voor doelmatig werken. Een en ander met behoud van transparantie.

7. Om draagvlak voor het veranderingstraject te creëren en te behouden is het van belang herkenbare stapjes te zetten en in de praktijk de voordelen zichtbaar te maken.

\section{I T E RAT U U R}

Algemene Rekenkamer, (2000), Rapport bij de financiële verantwoordingen over 1999, Den Haag, 17 mei 2000

Bestebreur, A. en R.P. van Oosteroom, (2000), De verbouwing gaat door; nieuw beleid rond agentschappen en begrotingsreserve, in: Overheidsmanagement, juni 2000.

Bogt, H.J. ter en G.J. van Helden, (2000), Resultaatsturing bij overheid kan beter, in: $E S B$, 22 september 2000.

Ministerie van Financiën, (1983), Beheersbaarheid van de collectieve uitgaven, zevende rapport van de studiegroep begrotingsruimte.

Ministerie van Financiën, (1991), Verder bouwen aan beheer, rapport van de heroverwegingsgroep beheersregels.

Ministerie van Financiën, (1998), Verder met resultaat; het agentschapmodel 1991-1997, brief aan de voorzitter van de Tweede Kamer der StatenGeneraal, Den Haag, 27 april 1998.

Oosteroom, R.P. van, P.G.J. Scholten en M.A. Soons, (2000), Financiering van baten-lastendiensten, in: Openbare Uitgaven, nummer 2.

Tweede Kamer, (1996), Van uitgaven naar kosten, vergaderjaar 1996-1997, 25.257, nummer 1.

Tweede Kamer, (1998a), Van beleidsbegroting tot beleidsverantwoording, vergaderjaar 1998-1999, 26.573, nummers 1 en 2.
Tweede Kamer, (1998b), Verslag van een algemeen overleg inzake de interdepartementale beleidsonderzoeken naar de bedrijfsvoering van overheidsdiensten, vergaderjaar 1998-1999, 26.250, nummer 3.

Tweede Kamer, (1999a), Tussenrapportage financieel beheer, vergaderjaar 1999-2000, 26.541 en 26.627 nummer 70.

Tweede Kamer (1999b), Nota over de toestand van 's rijks financiën (Miljoenennota 2000), vergaderjaar 1999-2000, 26.800 nummer 1.

Tweede Kamer, (1999c), Brief van de minister van Financiën inzake het voorbeeld Financieel Jaarverslag van het Rijk over 1999, vergaderjaar 1999-2000, 26.573, nummer 23.

Tweede Kamer, (1999d), Wijziging van enkele artikelen van de Comptabiliteitswet houdende onder andere de verdere invoering van het baten-lastenstelsel als begrotingsstelsel bij het Rijk en de invoering van een interne begrotingsreserve (zevende wijziging van de Comptabiliteitswet), vergaderjaar 1999-2000, 26.974, nummer A.

Tweede Kamer, (2000a), Nota over de toestand van 's rijks financiën (Miljoenennota 2001), vergaderjaar 2000-2001, 27.800, nummer 1.

Tweede Kamer, (2000b), Verslag van een OECD bijeenkomst inzake accrual accounting, vergaderjaar 2000-2001, 27.400, nummer 40.

Tweede Kamer, (2000c), Verslag van een algemeen overleg inzake hoofdstuk 4 van de Miljoenennota 2001 betreffende de integrale invoering van het baten-lastenstelsel, vergaderjaar 2000-2001, 27.400, nummer 41.

\section{NOTEN}

1 De auteurs bedanken drs. L.H. Kok, directeur Begrotingszaken bij het Ministerie van Financiën, voor zijn commentaar op een eerdere versie van het artikel.

2 Bij een aantal ministeries bleek de term agentschap negatieve associaties op te roepen van grote beleidsmatige afstand. Diensten die een baten-lastenstelsel voeren, gebruiken daarom voortaan de comptabele naam baten-lastendienst. Ze mogen zich overigens nog wel agentschap noemen.

3 Vanwege de onvergelijkbaarheid van het kasverplichtingenstelsel en het baten-lastenstelsel is geen zuivere maatstaf te formuleren voor de vergelijking van de omvang van de beide stelsels. Ter indicatie: de gerealiseerde baten over 1999 zijn gelijk aan circa 4\% van de totale uitgaven van het Rijk. Dit lijkt een laag percentage, maar beseft moet worden dat baten-lastendiensten geen programmagelden op hun begroting hebben staan. Wanneer het aantal medewerkers als maatstaf wordt genomen, dan is per 1 januari 2000 
circa $28 \%$ van het totale aantal rijksambtenaren werkzaam bij de baten-lastendiensten (Tweede Kamer, 1999c).

4 De eigenaar draagt de verantwoordelijkheid voor de bedrijfsvoering en voor het algehele functioneren van de desbetreffende overheidsdienst. De opdrachtgever dient de prijs/kwaliteitsverhouding te bewaken en vast te leggen in de met de overheids- diensten te maken (contract)afspraken.

5 De maximaal toegestane exploitatiereserve wordt uitsluitend bepaald door de hoogte van de omzet. De reden hiervoor is dat de risico's bij batenlastendiensten voornamelijk gelegen zijn in de exploitatiekosten die de kostprijs bepalen. Dure bezittingen hebben de baten-lastendienten nauwelijks, zodat een koppeling aan balansposten achterwege is gelaten. 